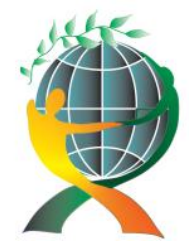

$$
\begin{gathered}
\text { (online) }=\text { ISSN } 2285-3642 \\
\text { ISSN-L }=2285-3642
\end{gathered}
$$

Journal of Economic Development, Environment and People

Volume 1, Issue 2, 2012

URL: http://jedep.spiruharet.ro

e-mail: office jedep@spiruharet.ro

\title{
Ethic of responsibility and the future of nature
}

\author{
Miso Kulic, PhD
}

\begin{abstract}
.
The question of science is the one that concerns the very foundations of our reality and, in addition to that, it is a question that deals not only with our natural reality, with what was once called the "natural nature", but also with social and technological reality produced by science itself, which for a long time now is our second nature. Science has become not only the instrument by which we try to understand the reality of nature, through the process of creating reality, forming and transforming nature, it has become the reality in which we live itself, and without which, as it seems, we could hardly go on living. However, even though science as an instrument for understanding reality has become the reality which we have produced ourselves, we are still, paradoxically enough, far from answering the essential question: What is science?

Since the question of science is at the same time the one of the production of reality, it is obvious that the question "what is science?" does not amount to a self-evident question asked by a scientist regarding his scientific field. It is not only a question concerning the nature of scientific knowledge, or of scientific methods of scientific results achieved. What is at stake here is the insight concerning social and political usage of science, that the reality, which is produced by the sciences, reveals to us even in the forms of its deification, manipulation, ideologization and virtualization. Is persevering in its science-Enlightenment paradigm of human emancipation or does it, on the wave of critical self-reflection spanning all the way through the 20th century, more and more question, as Paul Feyerabend (Against Method) does, the extent of constraints imposed on free thought which it produces itself? Of course, the other side of the questioning itself belongs here too: scientific progress can be evaluated regardless of its consequences, of the dangerous threats it poses to our future: nuclear annihilation, ecological pollution or climate changes which endanger the survival of the living world?
\end{abstract}

Keywords: question of science, social and technological reality, scientific progress

JEL Codes: 131, 120 


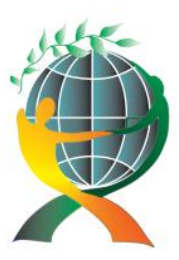

\author{
(online) $=$ ISSN $2285-3642$ \\ ISSN-L = $2285-3642$ \\ Journal of Economic Development, Environment and People \\ Volume 1, Issue 2, 2012 \\ URL: http://jedep.spiruharet.ro \\ e-mail: office jedep@spiruharet.ro
}

\title{
1. Introduction
}

Question about science ${ }^{1}$ is the question of the very foundations of our reality and in addition to that, it is an issue that concerns not only the natural reality, "natural nature" as it once was called, but also social, technical and technological reality that is produced by the science itself and which has already been our second nature for a long time. Science has become not only the instrument by which we understand the reality of nature, but producing a reality, shaping and transforming nature - it has now become the reality in which we live, and without which, it seems, it is more than difficult that we might live. However, although science as an instrument for understanding reality has become the reality that we have produced ourselves, we are still, paradoxically, far from essential answer to the question: what is science?

Since the question of science is at the same time the question about the production of reality, it is immediately shown that the question: what is science is not just about an implied question asked by scientists about their own science, therefore, it is not only a question concerning the nature of scientific knowledge, scientific methods or achieved scientific results, but there is also an insight on the social, political usage of science which is shown by the reality produced by science in the forms of its deification, manipulation, ideologization or virtualization. Is science still persisting in its Enlightenment paradigm of liberation of human, or is it, on a wave of critical self-reflection of science that is spanning through the entire twentieth century, more and more asking, as Paul Feyerabend is (Paul Feyerabend, Against Method), about the extent of suppressing free thought that is produced precisely by it, the modern science. Of course, the other side of the question also belongs here: whether the progress of science can be considered outside of its consequences, the dangerous threats of the future: nuclear annihilation, environmental pollution, or climate changes which endanger the survival of the living world?

It is clear that in the question of science any fragmentary or regional understanding of science is exceeded as something that in its special object is never related to the totality, but only in one particular region of reality that special science researches, precisely because the question of science became the

\footnotetext{
${ }^{1}$ This text was created as the result of working on the scientific project of the Ministry of Science of the Republic of Serbia on the topic: Research of the climate changes and its impact on the environment - monitoring the impact, adaptation and mitigation, no.43007
} 


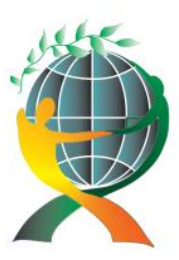

\author{
(online) $=$ ISSN $2285-3642$ \\ ISSN-L = $2285-3642$ \\ Journal of Economic Development, Environment and People \\ Volume 1, Issue 2, 2012 \\ URL: http://jedep.spiruharet.ro \\ e-mail: office jedep@spiruharet.ro
}

question of the whole life reality. The totality of reality has become almost the same as a scientific reality, because the totality of scientific reality appears as a true whole that understands the diversity of life in its unity. Therefore the idea of the unity of science and of interdisciplinary cooperation of special sciences is identical as the notion of a unique reality in its related environmental diversity.

\title{
2. Our study
}

This is the point where the question arises: is the ability to prevent natural disasters produced by a man - as seen in the dramatically altered climate - falls into the realm of finding an appropriate scientific and technological response, or the solution is, perhaps, in the fundamental change of irrational economic principle which is expressed in the insatiable aspirations for profit? However, it is at first sight noted that this dilemma presupposes such mutually connection between science and economics of the modern world, which, because of that is not a real dilemma, since it has become well-known that the essence of progress is raised into the principle which measures its own vitality only by faster and faster beats of profits. Thereby, science and its values are seen as the identity to this economic rhythm of the beats of the profit, in other words, the value became the same as the profit. Science is, without any doubt, subordinated to the economic interests of the society, to the system of value that comes from this interest, and although the question of science in this context is one more complex problem, it is safe to say that the process which is at work today witnesses to the completely changed relation of the powerful layers of modern society according to proclaimed universal right of the human to dispose with scientific results which are obtained.

For decades, scientific discoveries are no longer taking place where they have traditionally always happened: within universities, but within the institutes and laboratories of powerful financial corporations. Universities, despite their declarative definition, are less scientific and educational institutions as they were centuries since its creation, but are only areas for gaining education, but without a real and full involvement of teachers and students in the process of scientific work. It is true that there are arguments that consider that the implicit modern monopoly on science is the one which has a basis in real social relations. That is to say, the arguments used to defend this position of monopoly of the scientific research are always the one that is referring to the need of the safety of the society. However, as long as it in some respects was plausible argument, it should be said that even one thing of real life is not remained - from agriculture to nuclear power - which would not have entered into the question the safety of the society. Therefore indication to this type of security threat, may also be in the function of hiding strong totalitarian, profitmotivated economic tendencies of the modern democratic society, the same company that Herbert Marcuse described as "pleasant, well established, sensible, democratic lack of freedom" (Herbert Marcuse, One 


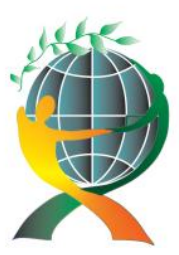

\author{
(online) $=$ ISSN $2285-3642$ \\ ISSN-L = $2285-3642$ \\ Journal of Economic Development, Environment and People \\ Volume 1, Issue 2, 2012 \\ URL: http://jedep.spiruharet.ro \\ e-mail: office jedep@spiruharet.ro
}

Dimensional Man). The problem becomes even further complicated when the egoism of the richest and the most powerful social class appears as a collective egoism. Even clearer, when it receives its global contours.

Because of that it is not difficult to establish today that the collective economic egoism, which is especially manifested in the question of the control of the use of natural resources, as the collective reduction of morality, since the question of global responsibilities cannot be seen beyond their own egoistic need of making profit. That is the reason why the universal moral principles are accepted only if they coincide to the own egoistic principle of increasing wealth and power. This fact precisely requires the question today: has the science, except being an "instrument of social progress", the right to, regardless of economic and political interests of society, put the issue about own autonomous ethical principles? Is for the ethics of responsibility of the modern world necessary to establish the demand about the necessity of thinking of possible consequences of scientific acknowledgements, or the ethical responsibility is left to the economic and political sphere, particularly to the area that sets itself up as a place of general judgments about ethics or lack of ethics of an act? Is not science and scientific acknowledgement too often presented in ideological terms only as "disinterested," "objective," "value-neutral", therefore something which shouldn't been wondered about the moral consequences of its knowledge? That is the reason why the dominant ideological belief of the twentieth century is managed to be established: that the ethical issue in science is beyond of its scientific discoveries, in other words beyond its "objective" research subject. In fact, it is about the ideological belief that the ethics can be found only in the appliance of scientific knowledge, and hence the ethic is out of science, since the appliance is out of its reach.

Therefore, it seems, the ethical discourse still need to recover and take into consideration the issues that were raised in front of the scientists when their work made the atomic bomb the part of our reality. Perhaps, therefore, of greatest importance is to re-enable the call to that inner sense of moral responsibility of the scientists that is so deeply, human and in responsible manner presented in the letter of Albert Einstein to the U.S. President Theodore Roosevelt, and in which Roosevelt was warned of the danger of appliance and abuse of the atomic bombs.

But today, the issue of climate changes is the one that could call into the question the very existence of life on the planet even more dramatically than the one the atomic bomb creators had. The usage of nuclear weapons can be controlled, and therefore its usage can be considered as something regional, because it does not necessarily and globally endanger the humanity. In distinction to, climate disturbance threatens the essence of nature, the substance on which the entire life of the planet is grounded on, so the climate change is the direct effect of industry created way of human life. If the science is tacit on or minimizes the cataclysmic consequences of climate changes, which is happened very often under pressure from the side of the large corporations, then the responsibility is not only in economic and political sphere. The ethic of 


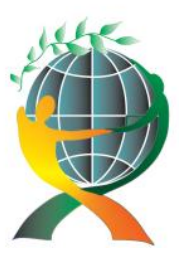

\author{
(online) $=$ ISSN $2285-3642$ \\ ISSN-L = $2285-3642$ \\ Journal of Economic Development, Environment and People \\ Volume 1, Issue 2, 2012 \\ URL: http://jedep.spiruharet.ro \\ e-mail: office jedep@spiruharet.ro
}

responsibility is also the autonomous responsibility of the science for the future of nature as the future of the living world, including, of course, humankind. A part of environmental history can be used as illustration, which took place from the 30 s of the twentieth century.

That is to say, if the question of nuclear waste, acid rains, toxic substances, or automobile exhaust gases something that could and can be solved regionally, the problems of climate changes are those which can be solved only on global level. For example, researchers like Clive Ponting (Clive Ponting, A New Green History of the World) noted that the reduction in the ozone layer, despite of numerous interstate and regional agreements, initially perceived a complete failure. This is an example in which a regionally problem has become global, but that could be partially solved on regional level. The problem that arose from the ozone layer, artificial chemicals, chlorofluorocarbons (CFC) presented the greatest problem, because, as Ponting quoted: one atom of chlorine is able to destroy one hundred thousand ozone molecules. Sprays, gases from refrigerators or air conditioners that used CFC, at the same time were becoming more and more cheaper in industrial production, and the consequence is giddily increase of CFC. The real problem arose when it is found that CFC does not decompose, and that all amounts of CFC that have ever been produced still persist in the atmosphere. CFC destroys the ozone layer which, in turn, by omission of ultraviolet radiation stimulates the appearance of skin cancer, cataracts, slows down the photosynthesis among plants, and destroys phytoplankton in the oceans which are the basis of nutrition of all living organisms in the sea. Clive Ponting recalls that numerous environmental organizations demanded an immediate ban on the usage of CFC, but that the powerful companies prevented that with the help of high-ranking officials, who have cynically claimed, as Secretary of Environment and State Planning of the United States did, "that the use of protective agents against the sun, hats and sunglasses, has more sense than to harm such an important American industry." However, international action was productive and very quickly found a replacement for CFC, but whole mankind will have to suffer from the hazardous consequences of such economic egoism and existential irrationalism through the whole next century. Therefore, the question that Clive Ponting predicated in his study sounds reasonable: are the modern societies environmentally sustainable? Whether, therefore, the ethics of responsibility in its demand for the future of nature as the future of humanity is also a requirement for different principles of social life? And the Science also?

Hans Jonas (Das Prinzip Verantwortung) was among the first who signified that the new ethics presupposes the natural world also, and that unlike the traditional one which was related only to human relationships, this new ethics must be also included into ecology. Insofar new ethics is based on the principle of accountability which is conceived completely differently from the principles of responsibilities of the traditional ethics. The ethics of responsibility is in fact one different attitude to the existence of the science 


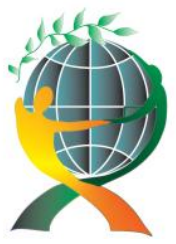

\author{
(online) $=$ ISSN $2285-3642$ \\ ISSN-L = $2285-3642$ \\ Journal of Economic Development, Environment and People \\ Volume 1, Issue 2, 2012 \\ URL: http://jedep.spiruharet.ro \\ e-mail: office jedep@spiruharet.ro
}

and technology, because it notes that the subordination of nature, which is imagined as happiness to people, led whole mankind to the edge of threat, if not to the edge of disaster of its own being. Therefore, this ethic of responsibility is at the same time the ethics of fear, according to the opinion of Hans Jonas, "only if we can predict the possibilities of human destruction, we will be able to reach to that idea of a man who should be saved from this." Therefore Jonas intercedes on the responsibility of the scientists, but at the same time he does not see a solution out of scientific and technological rationality, without which we can not solve problems which, otherwise, without them would not exist.

On the other hand, Herbert Marcuse believes that the rationality of the social system itself is problematic. Modern society transforms nature in technological manner and in that way it changes the basis of dominance, because the former personal dependence on a master replaces by the dependence on "objective order of things", i.e. on economic laws, markets, etc... Scientific organizations and the division of labor increased productivity in all areas of human life, but although the result is a higher standard of living, as one undoubted value, the price is paid by establishing of a new model of the human mind and behavior. In the name of such a high standard, the most destructive and the most oppressed parts of entrepreneurship were justified by subtle methods, and in this way the scientific and technical rationality and manipulation were combined to and shaped into the new forms of social control. Therefore, Marcuse asks himself, whether a man can be satisfied by the explanation that the unscientific outcome is the result of specific social application of the science? Indeed, it is not difficult to agree with Marcuse that the principle of scientific rationality produces irrationality, hence, that the unscientific principle of rationality of a man is applied against the man.

Although Marcuse does not have an answer on a specific form of a truly humane society, which is certainly not a defect, his critical blade is substantially opposite to that of Hans Jonas, because it is based on the critique of assumptions of possible solutions that indicates Jonas. For Jonas, the fear of the disastrous consequences of the transformation and exploitation of the nature is something that can possibly stop us. Certainly, it would be too harsh to say that Jonas thought that ethics of fear is the solution to the problem, because the fear in his philosophy of nature is something that just should face us to the consequences. Therefore, Jonas' valuable considerations are basically only the one that brings us near to the understanding that scientific-technological rationality faces the human with the fact that every advance in science is at the same time the one that has global consequences for the whole of life. Liability concerns not only the human but also totality world of life.

On the other hand, Marcuse believes that modern society is irrational precisely because its economic growth depends on the repression of the real possibilities for pacification, or - which is the other side of the same coin - because it maintains its peace by constant threat of war. Marcuse in his studies of the ideology 


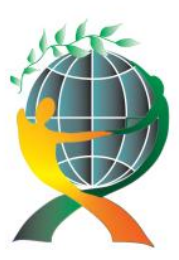

\author{
(online) $=$ ISSN $2285-3642$ \\ ISSN-L = $2285-3642$ \\ Journal of Economic Development, Environment and People \\ Volume 1, Issue 2, 2012 \\ URL: http://jedep.spiruharet.ro \\ e-mail: office jedep@spiruharet.ro
}

of the developed industrial society does not have a dilemma that the threat of nuclear catastrophe, that could destroy humanity, the one that serves to the preservation of the forces which perpetuate this danger. Developed industrial society becomes richer, bigger and better by perpetuating this danger, and thus the production of fear emerges as the one that encourages business and general progress. Fear for safety enables that political needs of a layer of society become individual needs. So fear is not only the ability to prevent trouble, but it could be the one that hides the real trouble. By this it is ensured that also these irrational foundations of social relations appear unproblematic.

Marcuse was the first who brought the cause of danger in clear connection with the way one society is organized, and so his theoretical assumptions of his consideration from the 60s of the twentieth century are almost identical to modern criticism according to which threat of global warming is seen as a delusion. Manipulation of saving the planet from climate changes, as critics believe, is supported and produced by HAARP, by the weapon that is capable of changing climate, produces earthquakes and destroys wildlife. So global warming associated with melting is nothing but an instrument for the production of global proportion fear. Hence, these critics consider that the global warming does not exist, but was designed only as a place for successful business and it is in fact only a plan of powerful bankers and industrialists to govern and exploit, primarily, the Third World countries.

However, if it is about global manipulation and not climate changes which are the result of irresponsible human relation to the nature - the question of profit still remains as an irrational economic relation that leads to apocalyptic events. The global threat is both and global and dangerous.

In this sense, climate changes, for the first time in history, face us to the possibility of global catastrophe. Global warming perhaps is no longer only an instrument of pacification, the production of fear in the function of profits and stability of the system, but it is the reality that faces humanity with the fact of the collective egoism of the rich countries and increasing inequalities among people. Rich countries have greater possibility than the poor countries to face the consequences of climate changes because the biggest resources of water and energy belong to them. Therefore, the future defined by global warming may lead to the appearance of environmental refugees, and thus to the conditions under which environmental refugees can be accepted or not. Ecological enslavement can quickly become our reality. UN Intergovernmental Panel on Climate Change IPCC (Intergovernmental Panel on Climate Change) and its reports on reduction of agricultural yields and the disappearance of many species are directly linked to the increase temperature. Some IPCC reports are particularly dramatic, because they indicate to the real possibility that the effects of global warming will especially befall the world of denominated inequalities. On the other hand, the solution 


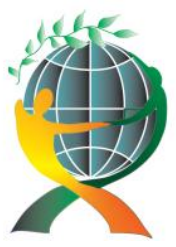

\author{
(online) $=$ ISSN $2285-3642$ \\ ISSN-L = $2285-3642$ \\ Journal of Economic Development, Environment and People \\ Volume 1, Issue 2, 2012 \\ URL: http://jedep.spiruharet.ro \\ e-mail: office jedep@spiruharet.ro
}

in reducing the current concentration of carbon dioxide, methane and nitrous oxide in the atmosphere could help, but the richest countries do not accept it. All hope is laid in the invention of new technology. However, there is no new technology, and if appeared it had to be the one that would not bring into question the principles of economic growth, as the Australian Prime Minister explained roughly.

\title{
3. Conclusions
}

All this shows that the economic and principles of social organization in general are based on the irrational pursuit of gaining profit by those who in the future, even though it would be found the new technology that would alleviate adverse climate changes, will not keep the humanity away from the dangers of global catastrophe. Moreover, global warming could lead to the disintegration of existing social systems and return the humanity to the natural struggle for survival. Another possibility is that the global threat which climate changes are carrying rapidly makes what history so far has never succeeded - to unite on the organic basis humanity and to lay the foundations of one more righteous society.

\section{References}

[1] John Bond, Professional ethics and corporate social responsibility, Process Safety and Environmental Protection, Volume 87, Issue 3, May 2009, Pages 184-190

[2] Kliment Arnaudov, Elena Koseska, Business Ethics and Social Responsibility in Tourist Organizations in Terms of Changing Environment, Procedia - Social and Behavioral Sciences, Volume 44, 2012, Pages 387-397 